\title{
Lactobacillus Spp. strains isolation, identification, preservation and quantitative determinations from the intestinal content and faeces of weaned piglets
}

\author{
Sorescu Ionut 1,2, Dumitru Mihaela ${ }^{* 1}$, Habeanu Mihaela ${ }^{1}$, \\ Stoica Costin ${ }^{3}$ \\ *Corresponding author: mihaela.dumitru22@yahoo.com
}

${ }^{1}$ National Research Development Institute for Animal Biology and Nutrition (IBNA), Biotechnology Laboratory, Balotesti, Ilfov, Romania;

2Present address: Institute for Diagnosis and Animal Health, 63 Dr. Staicovici, 050557

Bucharest, Romania;

${ }^{3}$ Address: Romvac Company, 7 Soseaua Centurii, Voluntari 077190, Ilfov, Romania

\section{ABSTRACT}

The study aimed to isolate, identify, preserve and evaluate the quantitative level of the Lactobacillus strains from gut content and faeces of weaned piglets, 30-107 days old; to test the viability of these strains preserved at $4^{\circ} \mathrm{C}$ and room temperature. Lactobacillus strains were isolated, phenotypically identified and preserved from gut content and faeces of 20 weaned piglets. Identification was performed by morphological, cultural and biochemical character examination, using apiweb ${ }^{\mathrm{TM}}$ and ABIS online software. Lactobacillus spp. from intestinal content and faeces $\left(10^{6}-10^{9} \mathrm{CFU} / \mathrm{g}\right)$ and the viability of strains preserved at $4^{\circ} \mathrm{C}$ and at room temperature were also determined (from 38 days to 4 months). Twenty-six strains of L. acidophilus, $L$. fermentum, L. plantarum, L. salivarius and L. delbrueckii ssp. delbrueckii, from gut content and faeces of weaned piglets were isolated, phenotypic identified and preserved. Of these, L. fermentum, $L$. delbrueckii ssp. delbrueckii and $L$. acidophilus biotype 2 isolates were technologically and ecologically suitable for continuing the testing of probiotic traits.

Keywords: Lactobacillus spp.; weaned piglets; phenotypic identification; preservation.

\section{INTRODUCTION}

The mammal's intestinal microbiota has beneficial roles for the host, in carbohydrates digestion, vitamins production, immune system regulation, and protection from pathogens (Buffie et al., 2013; Kamada et al., 2013). As a complex ecosystem, the pig intestinal microbiota is characterized by a 
dynamic composition (Isaacson and Kim, 2012). Gastrointestinal (GI) colonization is started at birth and is formed by saw's milk, which provide lactic acid bacteria (Frese et al., 2015). Escherichia coli and Streptococcus spp. create an anaerobic environment for Lactobacillus, Bifidobacterium, Bacteroides, and Clostridium (Petri et al., 2010). In the ilea of piglets at 26 days old, the most frequently identified genera included Lactobacillus, Clostridium, Streptococcus, Helicobacter, Ruminococcus, and Veillonella (Dowd et al., 2008). The most abundant genera at the age of 10-22 weeks included Prevotella, Lactobacillus, Blautia, Streptococcus, Faecalibacterium and Roseburia (Kim et al., 2011). There are bacterial genera that form an essential microbiota within the pig's GI tract regardless of country, diet, age or breed (Holman et al. 2017). Among all GI samples (including fecal samples), the genera Clostridium, Prevotella, Alloprevotella, Ruminococcus, Blautia, Lactobacillus, Roseburia, Subdoligranulum and RC9 gut group were found in more than $90 \%$ of all samples from 3-24 weeks old pigs. These taxa contain well-adapted bacteria to the pig's gut and, important, may serve as markers of a typical swine gut microbiota (Holman et al., 2017). The dietary transition and environmental changes at weaning are linked to modifying in piglet GI microbiota, which could be etiologically involved in enteric infections and post-weaning diarrhea (Lalles et al., 2007). Konstantinov et al. (2006), Su et al. (2008) and Wei et al. (2017) have informed a diminution in Lactobacillus and a loss of microbial diversity, whereas Clostridium spp., E. coli, Prevotella spp. was positively impacted through the weaning transition (Gresse et al., 2017). Lactobacillus spp. is recognised for its beneficial effects on the host's health (Duar et al., 2017). The sudden decrease of Lactobacillus spp., as major players in disease prevention, can amplify the increase of enteric infections (Konstantinov et al., 2006). Anyway, Lactobacillus is more abundant in the gastric mucosa, but is present in all types of GI samples, being able to attach to the epithelial and mucosal layers, where form biofilm-like communities (Pedersen and Tannock, 1989; van Winsen et al., 2001; Tannock, 2004; Walter 2008; Dumitru et al., 2020). Among these genus, L. fermentum, L. acidophilus, L. salivarius, L. sobrius, $L$. reuteri, $L$. plantarum, $L$. delbrueckii spp. bulgaricus and $L$. crispatus were most frequently detected (Pedersen and Tannock, 1989; De Angelis et al., 2006; Pieper et al., 2006; Janczyk et al., 2007). This diversity raises the issue of selecting the best strain for developing bacterial-based feed additives in pig nutrition. L. johnosii, L. mucosae, L. acidophilus, L. casei, L. plantarum, L. sobrius and L. rhamnosus were used as probiotic bacteria as different additives for pigs of 3-25 weeks old, with beneficial effects: decrease in E. coli (enterotoxigenic E. coli including), faecal coliforms and Clostridia, increase in Lactobacillus spp. and Bifidobacterium spp., decrease the incidence of diarheea, increase of villus height and higher production of short chain fatty acids (SCFAs) (Konstantinov et al., 2008; Zhang et al., 2010; Chiang et al., 2015; Barszcz et al., 2016; Dowarah et al., 2017; Shin et al., 2019; Wang et al., 
2019). Safety of piglets from postweaning infections by probiotics could occur through modulation of the resident GI microbiota (composition and activity), immune stimulation (stimulation of lymphocytes, production of antibodies and cytokines, improvement of intestinal barrier integrity) and pathogen inhibition (competition for sites of adherence, secretion of antibacterial molecules, inhibition of virulence genes) (Greese et al., 2017; Shin et al., 2019; Wang et al., 2019). In this perspective, the isolation and testing of Lactobacillus spp. strains as probiotic tools is a promising way for better management of a weaning transition, with non-antibiotic strategies able to restore a balanced GI microbiota (Greese et al., 2017; Wang et al., 2019).

The current study purpose to isolate, identify, preserve and assess the quantitative level of the Lactobacillus strains from the intestinal content and faeces of twenty weaned piglets, 30-107 days old, in order to further testing their probiotic traits and to select the best strains as intestinal flora stabilizers in pig diet.

\section{MATERIALS AND METHODS}

Pigs were treated in accordance with Romanian legislation (Law 199/2018) for handling and protection of animals used for experimental purposes.

Bacterial strains isolation and determination of $\mathrm{CFU} / \mathrm{g}$ intestinal content. The method of Mountzouris et al. (2007), adapted by Sorescu et al. (2019) was used in this study. Intestinal content (ileum and cecum, respectively) or faeces per capita, were collected from twenty weaned TOPIGS hybrid piglets, 30-107 days old.

Sample preparation: $1 \mathrm{~g}$ of sample was homogenized with $7 \mathrm{ml}$ Oxoid BHI (Brain Heart Infusion) broth and $2 \mathrm{ml}$ glycerol, and immediately frozen at $20^{\circ} \mathrm{C}$ until testing (no more of two months). After defrost, decimal dilutions in Oxoid PBS (Phosphate Buffered Saline) were done: $0.1 \mathrm{ml}$ from 10-4, 10-5, 10-6 dilutions, from every sample was inoculated on three Petri dishes with Oxoid MRS (Man, Rogosa, Sharpe) agar. The agar plates were cultural inspected. The procedure was presented in a previous paper (Sorescu et al., 2019) for the isolation and counting of Lactobacillus CFU from gut chickens. The colonies of each cultural type were calculated after 48 hours of anaerobic incubation (Oxoid jar with Anaerogen $2.5 \mathrm{~L}$ at $37^{\circ} \mathrm{C}$ ). Gram-stained smears of each colony type were made, for investigative morphological characters and confirmation of Lactobacillus.

\section{Bacterial strains identification}

Phenotypic identification of isolated bacterial strains was performed by morphological, cultural and biochemical characters examination, according to 
apiwebTM API50CHL software BioMerieux (France), Bergey's Manual of Systematic Bacteriology (Hammes and Hertel, 2009) and ABIS on line software (Stoica and Sorescu, 2018), following the protocol previously described (Sorescu et al, 2019). The results obtained by Pelinescu (2009) were also considered.

\section{Bacterial strains preservation}

The medium-term preservation (weeks, months) was done by culture in MRS broth, the bacteria viability being assessed after 38 days- 4 months. Longtime preservation (years) was done at $-80^{\circ} \mathrm{C}$, with addition of glycerol $20 \%$, and bacteria viability is to be evaluated every 2 years.

\section{RESULTS}

The taxonomic classification of Lactobacillus spp. was made through morphologically (Gram-positive, non-spore forming rods), culturally (anaerobic growth) and biochemically characters (negative catalase test). The identification of Lactobacillus spp. was performed based on their biochemical characters. Thus, twenty-six strains of the genus Lactobacillus (L. acidophilus biotype 1 IBNA 88, L. acidophilus biotype 2 IBNA 91, L. acidophilus biotype 3 IBNA 70, 76, 79, 81, 89, 93, 94, 96-99, L. fermentum biotype 1 IBNA 71, 75, 78, 85, 90, 92, 95, L. plantarum biotype 1 IBNA 84, L. salivarius IBNA 86, 87, 100 and L. delbrueckii ssp. delbrueckii IBNA 72, 77) were isolated, identified and preserved.

The morphological, cultural and biochemical traits of the identified strains are presented in Table 1. 


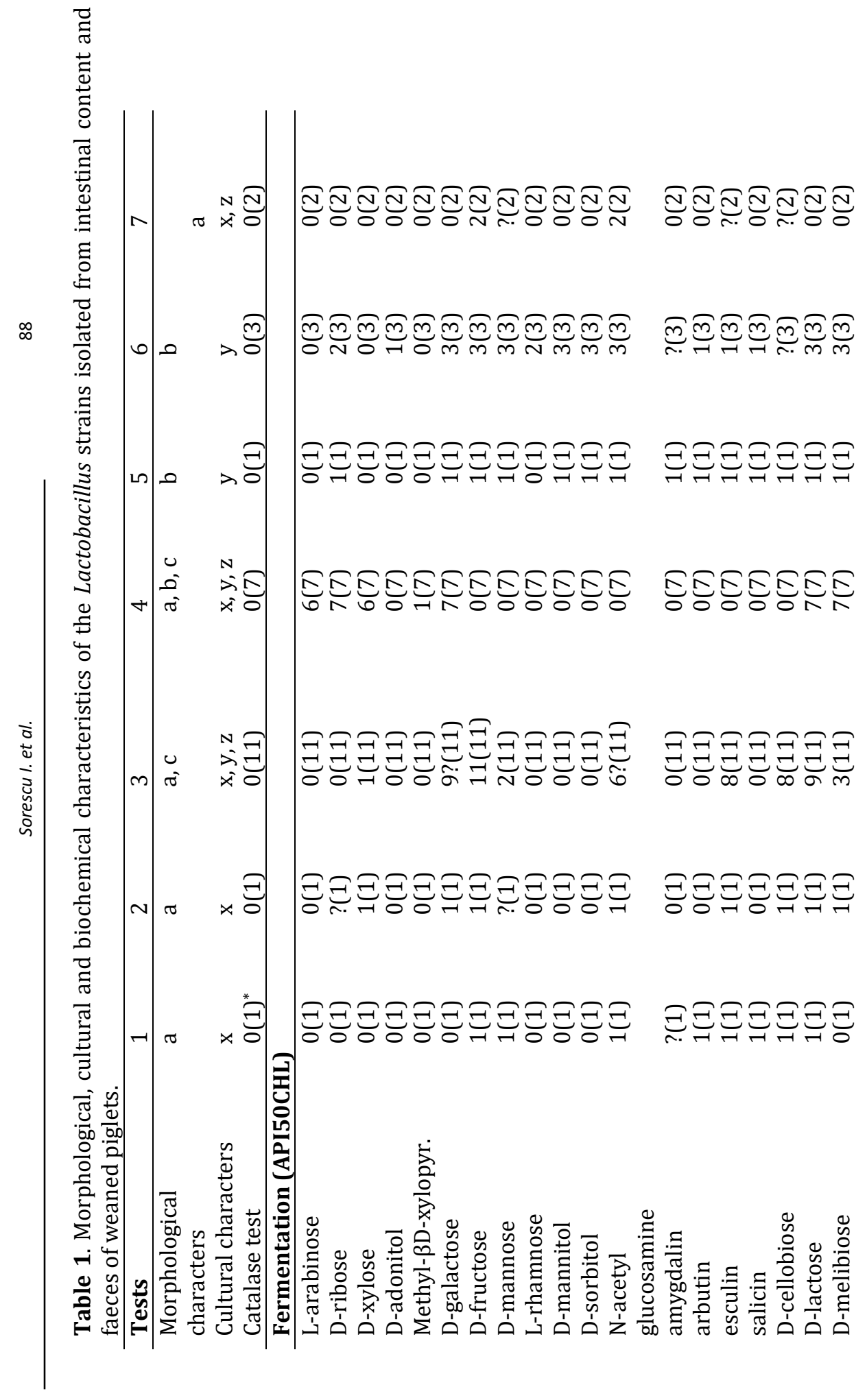




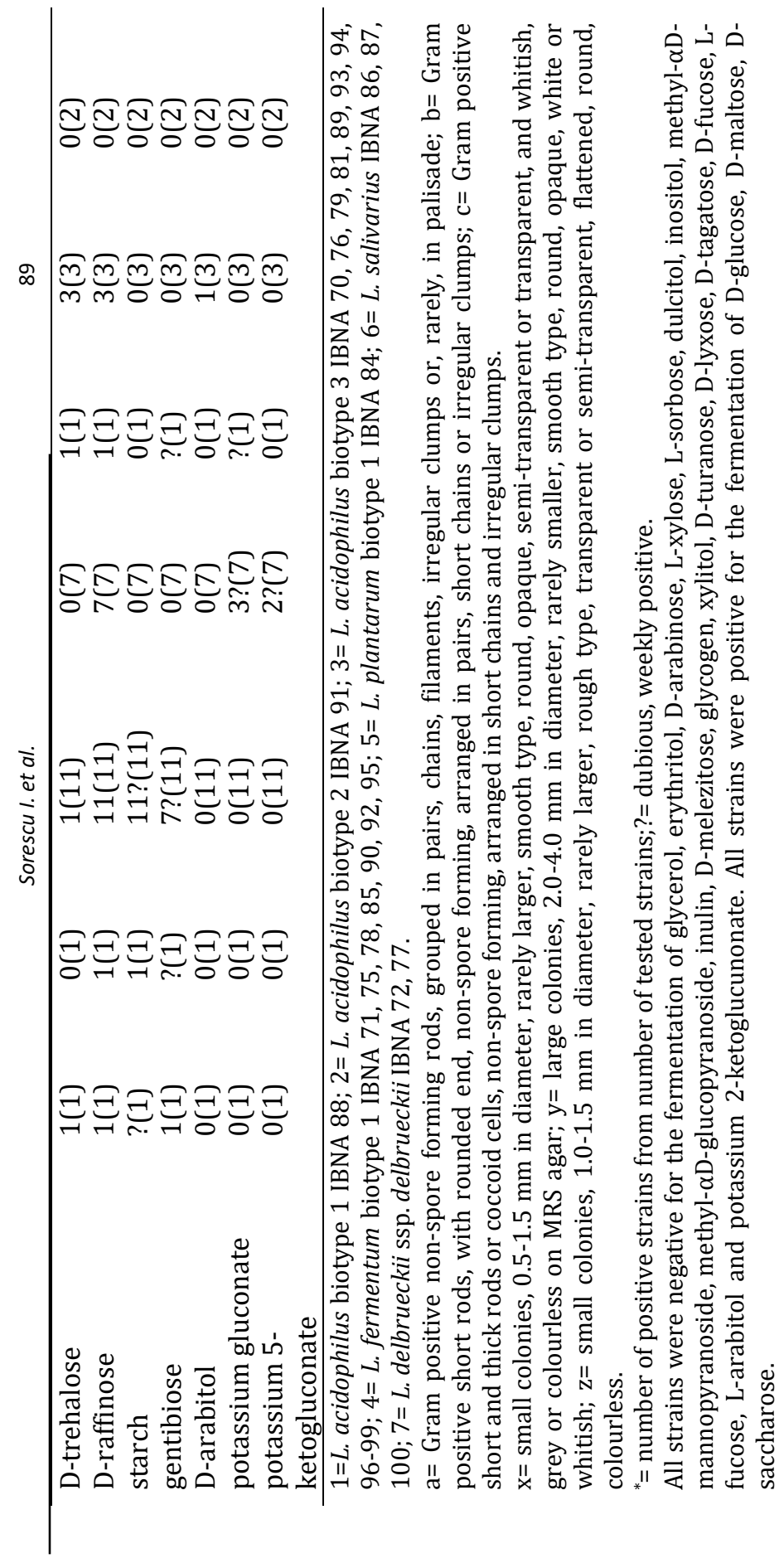


Figures 1-2 illustrate smears from $L$. acidophilus IBNA 88 and $L$. delbrueckii ssp. delbrueckii IBNA 72 cultures in/on MRS broth/agar (Gram staining, $\mathrm{x}$ 1000).

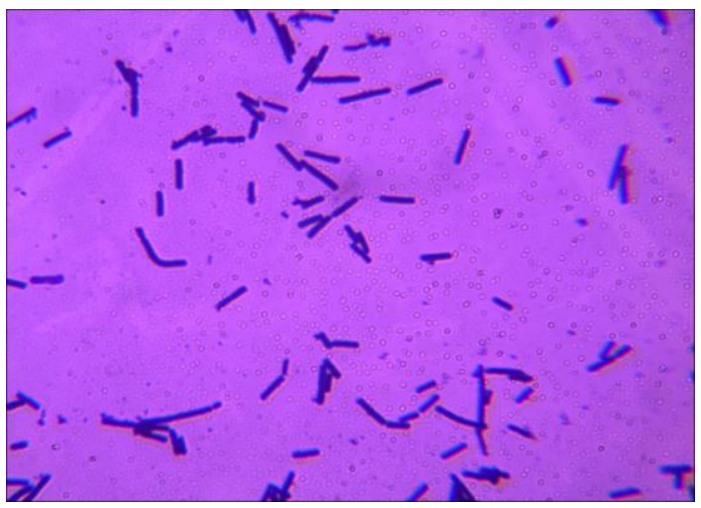

Figure 1. L. acidophilus IBNA 88 in MRS broth medium

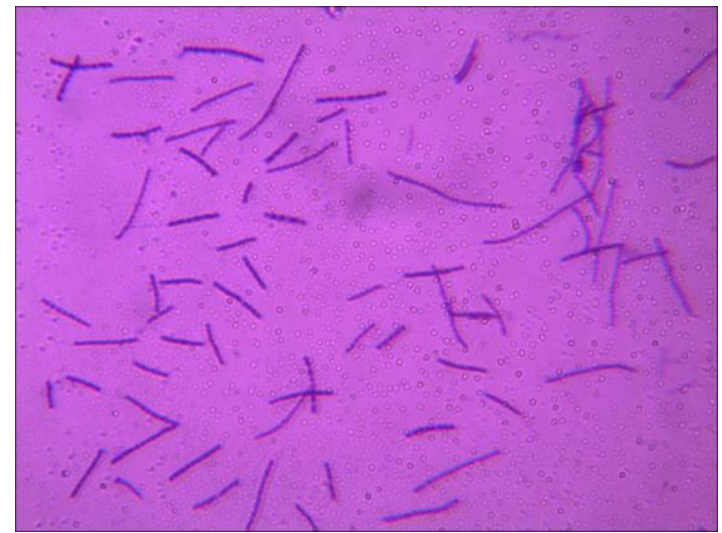

Figure 2. L. delbrueckii ssp. delbrueckii IBNA 72 on MRS agar medium

In Table 2 are presented the origin (faeces and intestinal content) and the level of the isolate's existence in the natural niche.

In Table 3 are presented the results of strains identification by apiweb ${ }^{\mathrm{TM}}$ soft, API50CHL V.5.1, BioMerieux (France), and ABIS online software.

Details on the meaning and mode of calculation of \% SIM for ABIS and API $\%$ ID were presented in a previous article (Sorescu et al., 2019).

In Table 4 are presented the results of the viability test for Lactobacillus strains which are preserved at $4^{\circ} \mathrm{C}$ and at room temperature. 
Table 2. The origin and the number of Lactobacillus spp. presence in the ecological niche (gut content and faeces of weaned piglets).

\begin{tabular}{|c|c|c|}
\hline Strains & Origin; sample number & $\begin{array}{l}\text { CFU/g intestinal } \\
\text { content }(\log 10)\end{array}$ \\
\hline $\begin{array}{l}\text { L. acidophilus } \\
\text { biotype } 1 \text { IBNA } 88\end{array}$ & faeces, 30 days old piglet; 109 (small colonies)*. & 8.51 \\
\hline $\begin{array}{l}\text { L. acidophilus } \\
\text { biotype } 2 \text { IBNA } 91\end{array}$ & faeces, 30 days old piglet; 112 . & 8.60 \\
\hline $\begin{array}{l}\text { L. acidophilus } \\
\text { biotype } 3 \text { IBNA 70, }\end{array}$ & $\begin{array}{l}\text { cecum content, } 81 \text { days old piglet; } 99 \text { (opaque, } \\
\text { large and smooth colonies). }\end{array}$ & 9.69 \\
\hline 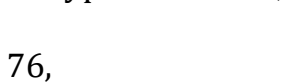 & $\begin{array}{l}\text { ileum content, } 81 \text { days old piglet; } 101 \text { (small and } \\
\text { smooth colonies). }\end{array}$ & 8 \\
\hline & ileum content, 107 days old piglet; 103 (opaque & 7.90 \\
\hline 79 & and smooth colonies). & \\
\hline 81, & $\begin{array}{l}\text { cecum content, } 107 \text { days old piglet; } 103 \text { (semi- } \\
\text { transparent and rough colonies). }\end{array}$ & 7.60 \\
\hline & faeces, 30 days old piglet; 110. & 8 \\
\hline $\begin{array}{l}89, \\
93,\end{array}$ & $\begin{array}{l}\text { faeces, } 30 \text { days old piglet; } 115 \text { (transparent and } \\
\text { rough colonies). }\end{array}$ & 8.39 \\
\hline & faeces, 30 days old piglet; 116. & 8.60 \\
\hline 94 & faeces, 30 days old piglet; 120 . & 8.90 \\
\hline 96, & faeces, 30 days old piglet; 121 . & 9.14 \\
\hline 97, & faeces, 30 days old piglet; 122 . & 9.90 \\
\hline $\begin{array}{l}98, \\
99 .\end{array}$ & $\begin{array}{l}\text { faeces, } 30 \text { days old piglet; } 126 \text { (small, } \\
\text { transparent and rough colonies). }\end{array}$ & 8.39 \\
\hline $\begin{array}{l}\text { L. plantarum } \\
\text { biotype } 1 \text { IBNA } 84\end{array}$ & ileum content, 107 days old piglet; 106. & 5.84 \\
\hline $\begin{array}{l}\text { L. delbrueckii ssp. } \\
\text { delbrueckii IBNA }\end{array}$ & $\begin{array}{l}\text { ileum content, } 81 \text { days old piglet; } 99 \text { (opaque, } \\
\text { large/middle and smooth colonies). }\end{array}$ & 8.30 \\
\hline 72 & cecum content, 81 days old piglet; 101 & 9.60 \\
\hline 77. & (large/small and rough colonies). & \\
\hline $\begin{array}{l}\text { L. fermentum } \\
\text { biotype } 1 \text { IBNA 71, }\end{array}$ & $\begin{array}{l}\text { cecum content, } 81 \text { days old piglet; } 99 \text { (semi- } \\
\text { transparent, large and rough colonies). }\end{array}$ & 8.77 \\
\hline 75 & ileum content, 81 days old piglet; 100. & 6.60 \\
\hline 78 & cecum content, 107 days old piglet; 102. & 7.30 \\
\hline 85, & ileum content, 107 days old piglet; 107. & 6.60 \\
\hline 90 , & faeces, 30 days old piglets; 112 . & 8.00 \\
\hline 92 , & faeces, 30 days old piglets; 115 (opaque and & 8.39 \\
\hline 95. & smooth colonies). & \\
\hline & faeces, 30 days old piglets; 119. & 8.30 \\
\hline L. salivarius IBNA & faeces, 30 days old piglets; 108. & \\
\hline 86, & faeces, 30 days old piglets; 109 (large colonies). & 7.54 \\
\hline 87, & $\begin{array}{l}\text { faeces, } 30 \text { days old piglets; } 126 \text { (large, opaque } \\
\text { and smooth colonies). }\end{array}$ & 7.87 \\
\hline 100. & & 9.39 \\
\hline
\end{tabular}

\footnotetext{
*= differential cultural characters only for the different strains isolated from same sample.
} 


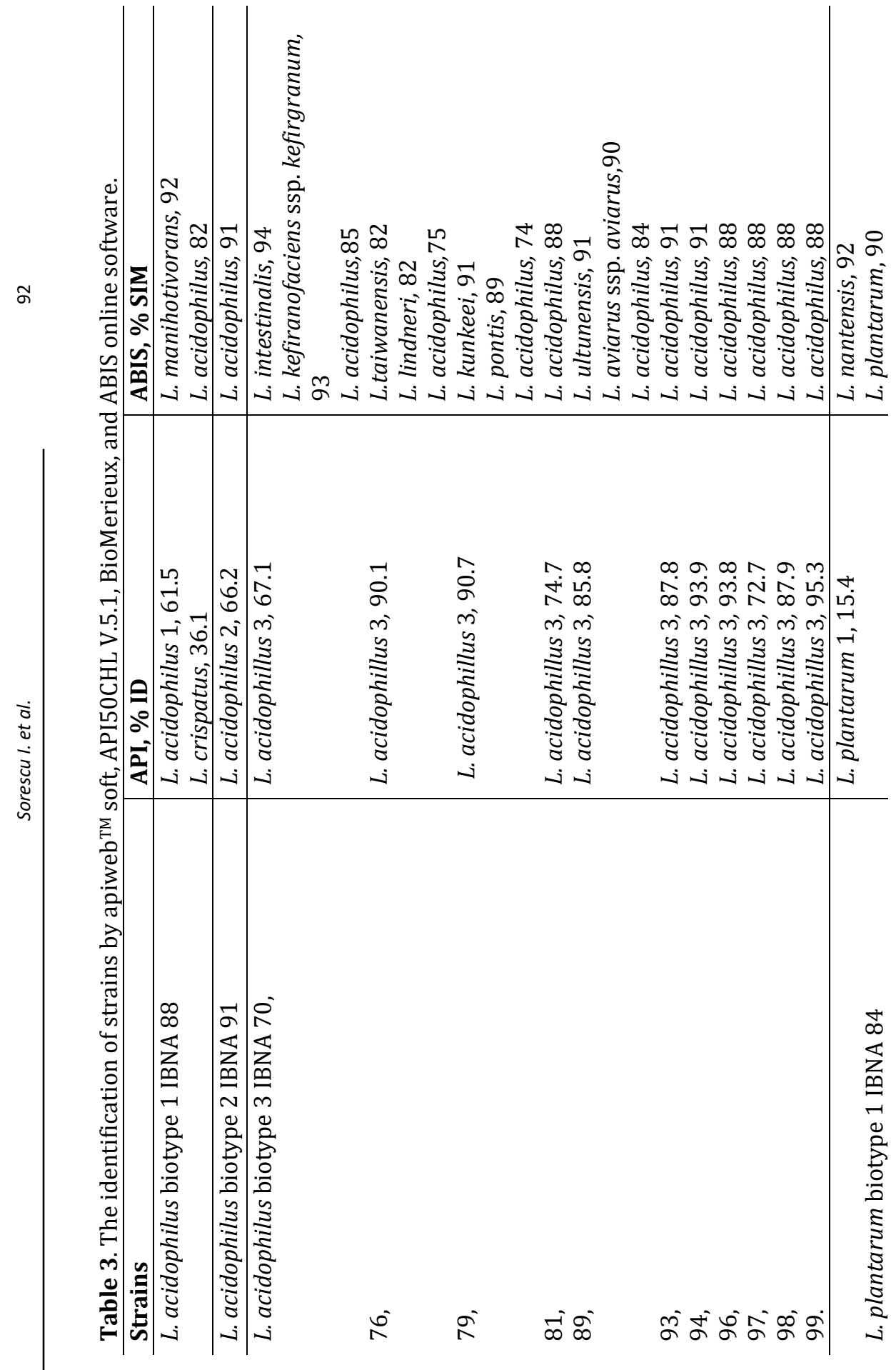




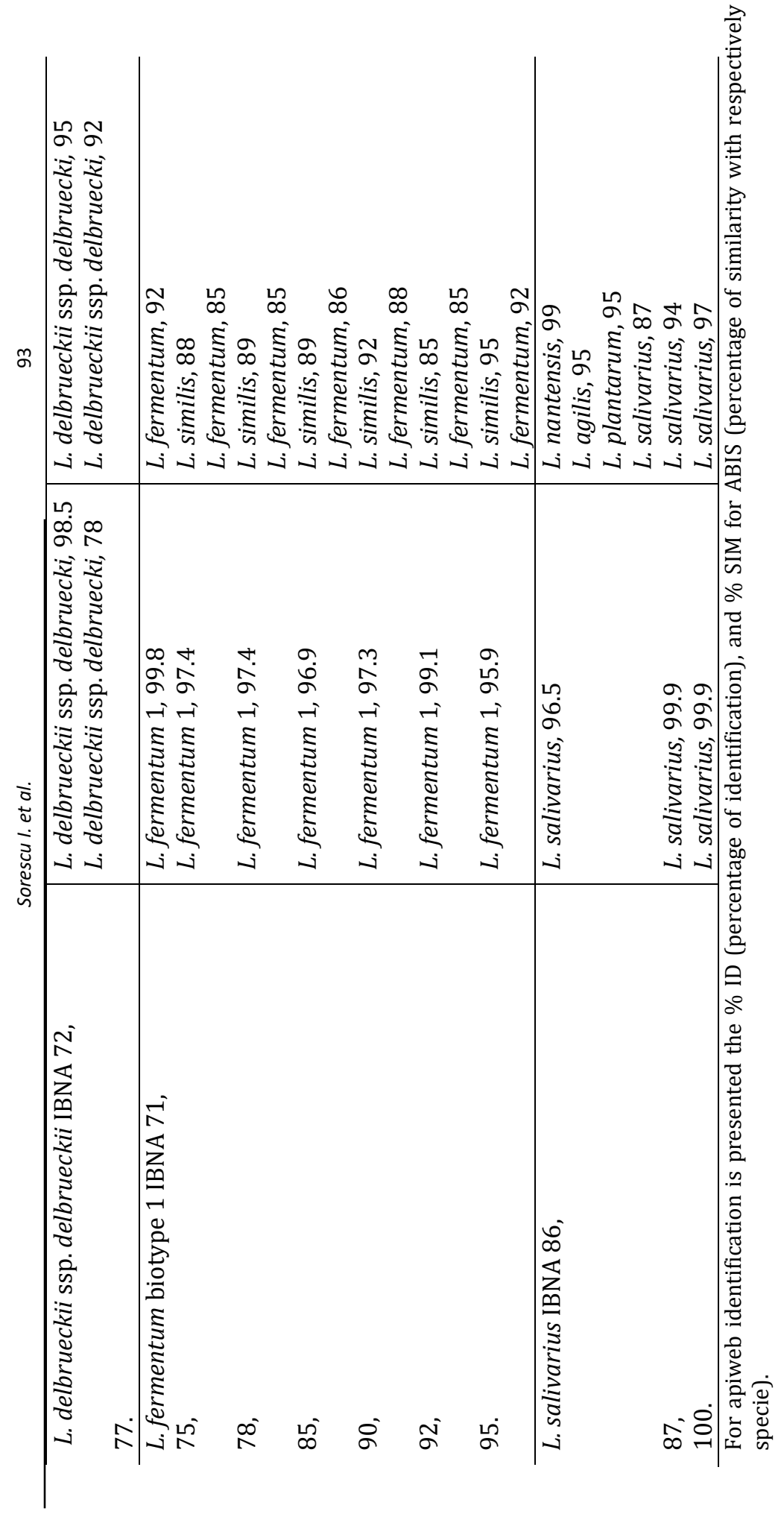


Table 4. The viability of Lactobacillus spp. strains preserved at $4^{\circ} \mathrm{C}$ and room temperature

\begin{tabular}{llc}
\hline Strains & Viability at $\mathbf{4}^{\circ} \mathbf{C}$ & $\begin{array}{l}\text { Viability at room } \\
\text { temperature }\end{array}$ \\
\hline L. acidophilus biotype 1 IBNA 88 & $\geq 45$ days & $<45$ days \\
L. acidophilus biotype 2 IBNA 91 & $\geq 45$ days & $\geq 45$ days \\
L. acidophilus biotype 3 IBNA 70, & $\geq 38$ days & 55 days \\
76, & $\geq 40$ days & $<70$ days \\
79, & $\geq 40$ days & $<60$ days \\
81, & 53 days & $<45$ days \\
89, & 45 days & 45 days \\
93, & $<55$ days & $\geq 56$ days \\
94, & $<55$ days & $<55$ days \\
96, & $<45$ days & $\geq 45$ days \\
97, & $<45$ days & $<45$ days \\
98, & $<45$ days & $<45$ days \\
99. & nd* & nd* \\
L. plantarum biotype1 IBNA 84 & $\geq 45$ days & $<45$ days \\
L. delbrueckii ssp. delbrueckii IBNA & 55 days & 38 days \\
72, & $\geq 40$ days & $<70$ days \\
77. & & \\
L. fermentum biotype 1 IBNA 71, & 55 days & 45 days \\
75, & 3.5 months & 2.5 months \\
78, & $\geq 4$ months & 2 months \\
85, & $\geq 4$ months & 45 days \\
90, & $\geq 45$ days & $\geq 45$ days \\
92, & $\geq 56$ days & $<55$ days \\
95. & $\geq 45$ days & $\geq 45$ days \\
L. salivarius IBNA 86, & $<45$ days & $<45$ days \\
87, & $<45$ days & $<45$ days \\
100. & nd* & nd* \\
*a not determinated & &
\end{tabular}

\section{DISCUSSION}

L. fermentum and L. plantarum are included in the itinerant lifestyle species group of lactobacilli. L. fermentum was isolated from plant material, mouth, milk products, sewage, humans faeces, and intestines of pig, rat, cattle, mouse and birds). L. plantarum was isolated from insects, vertebrate digestive tract, dairy products, plants, silage, outdoor environments. L. salivarius and $L$. acidophilus belongs to the vertebrate adapted lactobacilli group and were isolated from human, pigs, hamsters, horses and birds. L. delbrueckii ssp. delbrueckii is present in the human and animal intestinal tract (pig, mouse, 
rat), and vaginal tract (Duar et al., 2017; Stoica and Sorescu, 2018; Sorescu et al., 2019; Sorescu et al., 2020).

The strains described here, isolated from intestinal content and faeces of 30-107 days old pigs, could be important for developing probiotic compounds for the same species because they are host-adapted and have a high ecological compatibility. This characteristic is relevant in the process of outcompeting the pathogens.

Differentiation of Lactobacillus strains was performed as described before by Sorescu, (2019), mainly on the basis of some morphological characters (aspect of bacilli and grouping of them), some cultural characters (colony size, smooth or rough type, colour and degree of transparency/opacity) and especially, biochemical characters (fermentation of L-arabinose, D-ribose, Dxylose, D-galactose, D-fructose, D-mannose, L-rhamnose, D-mannitol, Dsorbitol, N-acetylglucosamine, amygdalin, arbutin, esculin, salicin, Dcellobiose, D-lactose, D-melibiose, D-trehalose, D-raffinose, starch, gentibiose). It can be noticed that strains of Lactobacillus isolated from pigs generally fermented more carbohydrates (26) than those from turkeys (15) (Sorescu et al., 2019) and chickens (21) (Sorescu et al., 2020), which may interfere with the absorption and metabolism of these carbohydrates in the host gut, if these strains are used in animal nutrition (Ciurescu et al., 2020).

As in turkeys (Sorescu et al., 2019) and chickens (Sorescu et al., 2020; Dumitru et al., 2020a) cases, in the intestinal cecum of weaned piglets (Dumitru et al., 2020b), the numbers of CFU lactobacilli/g were higher (107$\left.10^{9}\right)$ than in the ileum $\left(10^{5}-10^{8}\right)$, obviously especially in the case of isolation of the same species from both intestinal segments (L. acidophilus biotype 3, L. fermentum, L. delbrueckii ssp. delbrueckii). In faeces, the number of lactobacilli was similar to the cecum. L. acidophilus biotype 3, L. delbrueckii ssp. delbrueckii and L. salivarius strains had a relative higher presence (up to $10^{9}$ $\mathrm{CFU} / \mathrm{g}$ ) than other lactobacilli (up to $10^{8} \mathrm{CFU} / \mathrm{g}$ ), which suggests a possible ecologic and, therefore, probiotic advantage for them. This fact is interesting, because the L. acidophilus and L. salivarius strains are adapted to vertebrate species.

As phenotypic identification systems, both software (apiwebTM and ABIS) proved to be appropriate, especially for L. acidophilus biotype 2 and $L$. delbrueckii ssp. delbrueckii, where the same taxonomic classification was obtained, but with different percentage results, the way of calculating them being different. Instead, for L. acidophilus biotype 1 and L. fermentum biotype 1 , ABIS software is not yet refined enough for exact phenotypic identification.

Capability of probiotic strains to remain viable through storage and GI passage is an important trait during strains selection (Upadastra et al., 2011) and the resistance at $4^{\circ} \mathrm{C}$ and room temperature are applicable technologically characters of the strains, also. L. fermentum biotype 1 isolates resisted for the 
longest period of time, up to 4 months at $4^{\circ} \mathrm{C}$ and up to 2.5 months at room temperature. Strains from other species of Lactobacillus were, also, resistant at least 45 days ( $L$. delbrueckii ssp. delbrueckii, L. acidophilus biotype 3 and $L$. acidophilus biotype 2). These results are useful in screening the phenotypic characters of the candidate strains in order to formulate a probiotic product, involving resistance at least 45 days at $4^{\circ} \mathrm{C}$. The commercially successful probiotics were based on their technological robustness, they retaining viability during product shelf-life (O'Toole et al., 2017).

Considering the quantitative level of the Lactobacillus strains present in the ecological niche, the resistance at $4^{\circ} \mathrm{C}$ and room temperature and the $\%$ ID $\%$ SIM from identification systems, the L. fermentum biotype 1 (IBNA 71, 78), L. delbrueckii ssp. delbrueckii (IBNA 72, 77) and L. acidophilus biotype 2 (IBNA 91) strains only were selected for further testing of the probiotic characteristics.

\section{CONCLUSIONS}

The intestinal content (ileum and cecum) and faeces of twenty weaned piglets (30-107 days old) were used to isolate, phenotypically identify and preserve twenty-six strains of the genus Lactobacillus (L. acidophilus biotype 1-one strain, L. acidophilus biotype 2-one strain, L. acidophilus biotype 3eleven strains, L. plantarum-one strain, L. delbrueckii ssp. delbrueckii-two strains, $L$. fermentum biotype 1 -seven strains and L. salivarius-three strains). It was found that the number of lactobacilli in cecum content and faeces of weaned pigs is higher $\left(10^{7}-10^{9} \mathrm{CFU} / \mathrm{g}\right)$ than in the ileum $\left(10^{5}-10^{8} \mathrm{CFU} / \mathrm{g}\right)$ and L. acidophilus biotype 3, L. delbrueckii ssp. delbrueckii and $L$. salivarius strains had relative higher presence (up to $10^{9} \mathrm{CFU} / \mathrm{g}$ ) than other lactobacilli (up to $10^{8} \mathrm{CFU} / \mathrm{g}$ ). The Lactobacillus identification by apiwebTM API50CHL V.5.1, BioMerieux (France) software, and ABIS online software recovered similar results, especially for $L$. acidophilus biotype 2 and $L$. delbrueckii ssp. delbrueckii, where the taxonomic classification obtained was the same, but with different percentage results. L. fermentum biotype 1, L. delbrueckii ssp. delbrueckii, L. acidophilus biotype 3 and L. acidophilus biotype 2 isolates resisted for the longest period of time. Of the isolated Lactobacillus strains, those from $L$. fermentum biotype $1, L$. delbrueckii ssp. delbrueckii, and $L$. acidophilus biotype 2 are technically and ecologically suitable as potential probiotics and worth continuing the testing of their probiotic qualities.

\section{ACKNOWLEDGEMENTS}

This study was supported by Romanian Ministry of Research and Innovation through Sub-program 1.2 - Institutional Performance, Program 1 Developing national $\mathrm{R} \& \mathrm{D}$, National Research and Development and 
Innovation Contract no.17 PFE/ 17.10.2018 and Nucleu Program (project no. PN 190901 04).

\section{REFERENCES}

Barszcz M., Taciak M., Skomial J., 2016. The effects of inulin, dried Jerusalem artichoke tuber and a multispecies probiotic preparation on microbiota ecology and immune status of the large intestine in young pigs. Arch. Anim. Nutr.;70(4):278-292. doi: 10.1080/1745039X.2016.1184368.

Buffie C.G., Pamer E.G., 2013. Microbiota-mediated colonization resistance against intestinal pathogens. Nat Rew Immunol.;13(11):790-801. doi: 10.1038/nri3535.

Chiang M.L., Chen H.C., Chen K.N., Lin Y.C. et al., 2015. Optimizing production of two potential probiotic lactobacilli strains isolated from piglet feces as feed additives for weaned piglets. Asian Australas J Anim Sci.;28(8):1163-1170. doi: 10.5713/ajas.14.0780.

De Angelis M., Siragusa S., Berloco M., Caputo L. et al., 2006. Selection of potential probiotic lactobacilli from pig feces to be used as additives in pelleted feeding. Res Microbiol.; 157: 792-801. doi: 10.1016/j.resmic.2006.05.003.

Dowarah R., Verma A.K., Agarwal N., Patel B.H.M., Singh B.P., 2017. Effect of swine based probiotic on performance, diarrhoea scores, intestinal microbiota and gut health of grower-finisher crossbred pigs. Livest Sci.;195:74-79. doi: 10.1016/j.livsci.2016.11.006.

Dowd S.F., Callaway T.R., Morrow-Tesch J., 2007. Handling may cause increased shedding of Escherichia coli and total coliforms in pigs. Foodborne Pathog Dis.;4(1):99-102. doi: 10.1089/fpd.2006.53.

Duar R.M., Lin X.B., Zheng J., Martino M.E., Grenier T. et al., 2017. Lifestyles in transition: evolution and natural history of the genus Lactobacillus. FEMS Microbiol Rev.;30(41):27-48. doi: 10.1093/femsre/fux030.

Dumitru M, Habeanu M, Lefter Na, Gheorghe A., 2020. The effect of Bacillus licheniformis as direct-fed microbial product on growth performance, gastrointestinal disorders and microflora population in weaning piglets. Rom Biotechnol Lett.;25(6):2060-2069. doi: 10.25083/rbl/25.6/2060.2069.

Frese A., Parker K., Calvert C.C., Milla D.A., 2015. Diet shapes the gut microbiome of pigs during nursing and weaning. Microbiome;3:28-37. doi: 101186/s40168-015-0091-8.

Greese R., Chaucheyras-Durand F., Fleury M.A., Van de Wiele T. et al., 2017. Gut microbiota dysbiosis in postweaning piglets: understanding the keys to health. Trends Microbiol.;25(10):851-873. doi: 10.1016/j.tim.2017.05.004. 
Hammes W.P., Hertel C., 2009. Genus I. Lactobacillus Beijerinck 1901. In: Vos PD, Garrity G, Jones D, Krieg NR et al. (eds.), 2009. Bergey's Manual of Systematic Bacteriology;3: The Firmicutes. Springer, New York:465511.

Holman D.B., Brunelle B.W., Trachsel J., Allen H.K., 2017. Meta-analysis to define a core microbiota in the swine gut. mSystems;2(3):e00004-17. doi: 10.1128/mSystems.00004-17.

Isaacson R., Kim H.B., 2012. The intestinal microbiome of the pig. Anim Health Res Rew.;13(1):100-109. doi: 10.1017/S1466252312000084.

Janczyk P., Pieper R., Smidt H., Souffrant W.B., 2007. Changes in the diversity of pig ileal lactobacilli around weaning determined by means of $16 \mathrm{~S}$ rRNA gene amplification and denaturing gradient gel electrophoresis. FEMS Microbiol Ecol.;61(1):132-140. doi: 10.1111/j.15746941.2007.00317.x.

Kamada N., Seo S.U., Chen G.Y., Nunez G., 2013. Role of the gut microbiota in immunity and inflammatory disease. Nat Rew Immunol.;13(5):321335. doi: $10.1038 /$ nri3430.

Kim H.B., Borewicz K., White B.A., Singer R.S., Sreevatsan S. et al., 2011. Longitudinal investigation of the age-related bacterial diversity in the feces of commercial pigs. Vet Microbiol.;153(1-2):124-133. doi: 10.1016/j.vetmic.2011.05.021.

Konstantinov S.R., Awati A.A., 2006. Williams B.A., Miller B.G. et al., 2006. Postnatal development of the porcine microbiota composition and activities. Environ Microbiol.;8(7):1191-1199. doi: 10.1111/j.14622920.2006.01009.x.

Konstantinov S.R., Smidt H., Akkermans A.D., Casini L. et al., 2008. FEMS Microbiol Ecol.;66(3):599-607. doi: 10.1111/j.15746941.2008.00517.x.

Lalles J.P., Bosi P., Smidt H., Stokes C.R., 2007. Weaning - a challenge to gut physiologists. Livest Sci.;108(1-3):82-93. doi: 10.1016/j.livsci.2007.01.091.

Mountzouris K.C., Tsirtsikos P., Kalamara E., Nitsch S. et al., 2007. Evaluation of the efficacy of a probiotic containing Lactobacillus, Bifidobacterium, Enterococcus, and Pediococcus strains in promoting broiler performance and modulating cecal microflora composition and metabolic activities. Poult Sci.;86(2):309-317. doi: 10.1093/ps/86.2.309.

O'Toole P.W., Marchesi J.R., Hill C., 2017. Next-generation probiotics: the spectrum from probiotics to live biotherapeutics. Nat Microbiol.;2(art. no.17057):1-6. doi: 10.1038/nmicrobiol 2017.57. 
Pedersen K., Tannock G.W., 1989. Colonization of the porcine gastrointestinal tract by lactobacilli. Appl Environ Microbiol.;55(2):279-283. doi: 10.1128/AEM.55.2.279-283.1989.

Pelinescu D.R., Săsărman E., Chifiriuc M.C., Stoica I. et al., 2009. Isolation and identification of some Lactobacillus and Enterococcus strains by a polyphasic taxonomical approach. Rom Biotechnol Lett.;14(2):42254233.

Petri D., Hill J.E., Van Kessel A.G., 2010. Microbial succession in the gastrointestinal tract (GIT) of the preweaned pig. Livest Sci.;1-3:107109. doi: 10.1016/j.livsci.2010.06.037.

Pieper R., Janczyk P., Schumann R., Souffrant W.B., 2006. The intestinal microflora of piglets around weaning - with emphasis on lactobacilli. Arch Zootech.;9:28-40.

Shin D., Chang S.Y., Bogere P., Won K. et al., 2019. Beneficial roles of probiotics on the modulation of gut microbiota and immune response in pigs. PLoS ONE.;14(8):e0220843. doi: 10.1371/journal.pone.0220843.

Sorescu I., Dumitru M., Ciurescu G., 2019. Lactobacillus spp. and Enterococcus faecium strains isolation, identification, preservation and quantitative determinations from turkey gut content. Rom Biotechnol Lett.;24(1):41-49. doi: 10.25083/rbl/24.1/41.49.

Sorescu I., Dumitru M., Ciurescu G., 2020. Lactobacillus spp. strains isolation, identification, preservation and quantitative determinations from gut content of 26 days old chickens. Rom Biotechnol Lett., in press.

Stoica C., Sorescu I., 2018. ABIS online-Advanced Bacterial Identification Software, an original tool for phenotypic bacterial identification. Regnum Prokaryotae. Available online: www.tgw1916.net. (accesed on June 1, 2018).

Su Y., Yao W., Perez-Gutierrez O.N., Smidt H., Zhu WY., 2008. Changes in abundance of Lactobacillus spp. and Streptococcus suis in the stomach, jejunum and ileum of piglets after weaning. FEMS Microbiol Ecol.;66(3):546-555. doi: 10.1111/j.1574-6941.2008.00529.x.

Tannock G.W., 2004. A special fondness for lactobacilli. Appl Environ Microbiol.;70(6):3189-3194. doi: 10.1128/AEM.70.6.3189-3194.2004.

Upadrasta A., Stanton C., Hill C., Fitzgerald G. et al., 2011. Improving the stress tolerance of probiotic cultures: recent trends and future directions. In: Tsakalidou E., Papadimitriou K. (eds.). Stress Responses of Lactic Acid Bacteria. Springer, New York:395-438.

Van Winsen R.L., Urlings B.A., Lipman I.J., Snijders J.M. et al., 2001. Effect of fermented feed on the microbial population of the gastrointestinal tracts of pigs. Appl Environ Microbiol.;67(7):3071-3076. doi: 10.1128/AEM.67.7.3071-3076.2001. 
Walter J., 2008. Ecological role of lactobacilli in the gastrointestinal tract: implications for fundamental and biomedical research. Appl Environ Microbiol.;74(16):4985-4996. doi: 10.1128/AEM.00753-08.

Wang T., Teng K., Liu Y., Shi W. et al., 2019. Lactobacillus plantarum PFM 105 promotes intestinal development through modulation of gut microbiota in weaning piglets. Front Microbiol.;10:90. doi: 10.3389/fmicb.2019.00090.

Wei H.K., Xue H.X., Zhou Z.X., Peng J., 2017. A carvacrol-thymol blend decreased intestinal oxidative stress and influenced selected microbes without changing the messenger RNA levels of tight junction proteins in jejunal mucosa of weaning piglets. Animal;11(2):193-201. doi: $10.1017 / \mathrm{S} 1751731116001397$.

Zhang L., Xu Y.Q., Liu H.Y., Lai T. et al., 2010. Evaluation of Lactobacillus rhamnosus GG using an Escherichia coli K88 model of piglet diarrhoea: Effects on diarrhoea incidence, faecal microflora and immune responses. Vet Microbiol.;141(1-2):142-148. doi: 10.1016/j.vetmic.2009.09.003. 